\title{
Review
}

\section{Parliamentarism and democratic theory: Historical and contemporary perspectives}

\author{
Kari Palonen and José María Rosales (eds.) \\ Verlag Barbara Budrich, Opladen and Toronto, 2015, 240 pp., \\ ISBN: 978-3847401582
}

Contemporary Political Theory (2017) 16, 172-175. doi:10.1057/cpt.2015.71;

advance online publication 19 January 2016

If one thing is true of the wide and diverse field of democratic theory, it is the inevitability of a multi-disciplinary approach. If we define democratic theory, as the editors of this book do, as 'the theoretical study of democracy as differentiated from empirical research' (p. 11), then we can say that the relevant disciplines involved are, at least, democratic theory itself, historical research, empirical research (political science) and political philosophy. While the first two disciplines dominate the book under review, the last-named discipline offers the perspective from which this review is written.

From this angle, two things can be stated. The first is that democratic theory does, perhaps habitually, rather than necessarily, assume that we already are living 'in democracies' and that hence it offers an insiders' perspective. Democratic theory often tends to be theory of the people, for the people and by the people, as if 'we' must decide about the many meanings of 'democracy' and it tends to exclude the political-philosophical perspective that, to put it in Rancière's (2011, p. 78) words, 'being fought over is what makes a political notion properly political ..., not the fact that it has multiple meanings'. Not only is democracy clearly one of the 'essentially contested concepts' - democracy is also about contestation, and this contestation thus 'enters' the very concept. What is needed in political philosophy is the outsiders' perspective, which is not a Rawlsian 'view from nowhere', but rather the point of view of the 'part that is no part'. To put it bluntly: if you want to know what democracy is, ask a Syrian refugee.

The second point to make is that the study and discussion of democracy cannot be interdisciplinary, as if the right combination of disciplines would yield the true and complete picture, but can only be multidisciplinary: the field of academic study of democracy is always, also, a battlefield, usually of course with non-violent, discursive means. There is, to put it differently, a remaining gap between studying,

(c) 2016 Macmillan Publishers Ltd. 1470-8914 Contemporary Political Theory Vol. 16, 1, 172-175 www.palgrave.com/journals 
assessing, improving and questioning 'actually existing democracy' - different perspectives and disciplines can certainly inform each other, but they do not, nor should they, lead to a synthetic account.

Against this backdrop, the book under review, edited by two eminent specialists in the field of the history of political and social concepts, strikes a fine balance between conceptual and historical approaches. It contains highly informative and instructive contributions on, for example: academic societies in Great Britain as forerunners of parliamentarism (p. 56f); the parallel between scientific controversy and parliamentary deliberation in the work of Max Weber, both turning around pro et contra argumentation as a way of coming as close as possible to objective scientific truth, on the one hand, and the objectively [sachlich] best political decision, on the other (p. 106); and the ongoing complaints regarding parliamentarism in the interbellum, targeting both universal suffrage and proportional representation, as well as various proposals for its improvement, both of which contain elements and topoi that are strikingly similar to present-day discussions both national and international. We can easily transpose the sentence that 'there was hardly anything new' in 'the omnipresent talk of the 'crisis of parliamentarism' in the 1920s and 1930s' (p. 133), to present-day 'omnipresent talk of the crisis of democracy'.

Gathered under the heading 'The Changing Uses of Parliamentarism', these chapters (together with several other historical contributions) are nicely complemented by six further chapters under the umbrella of 'Debating Democratic Theory and Performance'. These chapters discuss more theoretical topics as well as some suggested proposals for the improvement of parliamentary representative democracy as we think we know it. In the first category, the reader finds, among others, discussions in which: it is argued that fair compromise is better understood as a result of bargaining under fair conditions than as a second-best outcome of deliberation (p. 203f); or in which the question is raised whether participation is best understood as a supplement to or as a substitute for parliamentary democracy, a question that, rather than to a clear-cut answer, leads to a set of further questions (p. 295), each of which harbours both academic potential and political relevance.

For example, the issue is raised whether the involvement of citizens in the executive 'implementation of choices and priorities that have already been made' (habitually called 'democratization of governance') is not effectively turning this participation into a 'rubber stamp of legitimacy for the exercise of government power rather than a voice concerning broader public demands and contested visions' (p. 295). In this section, one also finds a discussion of alternative forms of deliberation through mini-publics and of sortition as an alternative selection mechanism for voting - is it accidental that Microsoft Word does not recognize the word 'sortition' as a correct English word? What becomes clear here is that innovative reform of the electoral-parliamentary system that 
is in place in so many 'stable democracies' is not a matter of good ideas or creative designs, but rather of the resistance of established actors, such as the traditional political parties, which rightly fear that their exclusive grip on political power, and, more importantly, its legitimacy, might be undermined (p. 182).

The volume as a whole raises more questions than it answers. This, however, might be precisely what 'we' (any self-determining democratic 'we') need at this point in history. History is what proves to be instructive. One thing that we can learn from this volume is that both 'crisis of democracy' and 'mob rule' have been accompanying ideologemes of representative democracy since it began to dominate, first normatively, then also empirically. From this angle, present-day phenomena like right-wing populism or the (technocratic and chauvinist) call for a 'strong (wo)man', which are quickly gaining force in Europe, are certainly a cause for alarm for anybody who cherishes freedom, openness and plurality. However, there is nothing particularly new about them; nor is the phenomenon limited to the so-called 'new democracies' in the former Warsaw pact region. What is arguably new is the European context in which, and increasingly also at which, they articulate themselves. A recent example would be the spread of Pegida, which started in the German far east, to The Netherlands. Paradoxically, the anti-Islamic movement in Europe is often explicitly European. They oppose Eurabia even more paradoxically, perhaps, networks of radical Islamists do not care about national borders, either.

Another thing that we can learn is that, like any other political system, parliamentary democracy displays a tendency towards stabilization, petrificiation and ossification, becoming not necessarily a dead letter, but in crucial ways an obstacle to its own creative innovation. This leads to a specifically democratic deadlock, because democracy is the attempt to organize and facilitate change by legitimizing and channelling conflict, but the extent to which this indeed works depends critically on the stability of democratic constitutions, provided that they warrant freedom of gathering, association, organization, press and so on. As a result, existing democracy cannot be easily disqualified as an ancien régime in the way that absolute monarchy, European fascism, or, most recently, Soviet-style 'actually existing socialism' could.

Not only in theory, but in practice, liberal democracy largely offers the means necessary to channel conflict in any conceivable direction, and thus is the victim of its success rather than of its failure. The way out of this deadlock, I suggest, is twofold: on the one hand, to turn democratic theory partly into a laboratory of democratic forms irrespective of their chance at realization. This is what the volume under review indeed does. On the other hand, to start experimenting, in a grass roots manner, with local forms of democracy, perhaps initiating a bottom-up development, but remaining sceptical of any top-down attempt to welcome it. 


\section{Reference}

Rancière, J. (2011) Democracies against democracy: An interview with Eric Hazan. In: G. Agamben et al. (eds.) Democracy in What State? New York: Columbia University Press.

Evert van der Zweerde

Radboud University, 6525 HP Nijmegen, The Netherlands

e.vanderzweerde@ftr.ru.nl 